\title{
Political Economy of Fishing Villages: A Case Study in the Tonle Sap Lake, Cambodia
}

\author{
Mak Sithirith \\ Department of Natural Resource Management and Development, Royal University of Phnom Penh, Phnom Penh 12101, Cambodia
}

\begin{abstract}
The Tonle Sap Lake is home to three types of communities: land-based, water-based and land-water based communities, whose livelihoods are dependent on Lake's resources. This paper examines how fishing communities in the Tonle Sap Lake make their living in the context of declined resources, increased competition between fishers, the resources politics and the increased trades around the Lake. The paper concludes that in the old day, communities around the lake were related to one another through bartering rice and fish. However, at present, as resources declining, these communities compete over resources, and in doing so, they build relationship and connection with powerful elites including officials, fish traders and the fishing operators, who could protect them in fishing. As a consequence, fishers are trapped in the webs of vicious cycle of poverty, conflicts, corruption and patronage system and exploited and sucked in these webs.
\end{abstract}

Key words: Communities, livelihoods, market economy, bartering, resource decline, competition, fish trader.

\section{Introduction}

'When I was young, I saw fish abundances in the Tonle Sap Lake. I paddled by boat, fish jumped in and if I took a long ride, I could get almost enough fish for my meal. At present, we use a small mesh size net to fish; we still catch less fish'. Om Chhim, fisher in Kampong Phluk, 75 years old.

This is one of many stories narrating the resources change in the Tonle Sap Lake. The Lake is a largest freshwater Lake in Southeast Asia, where large volumes of water from the Mekong River flow into the Lake in the wet season, expanding the Lake's size 5-6 times larger than in the dry season, with the water level increased from less than $2 \mathrm{~m}$ to $9-10 \mathrm{~m}$ [1-3]. The Lake is home to more than 1.7 million people [4], living in three different villages - land-based village, the water based village and the land-water based village $[5,6]$. They live dependent on Lake's resources for subsistence livelihoods. However, communities are allowed under the Fisheries Law to fish in small scale. The subsistence in this case means that fishing is only

Corresponding author: Mak Sithirith, Ph.D., research fields: environmental and resource governance. for household consumption and not for trade [7].

Scott, J. [8] introduces the 'moral economy of the peasant' as the base of the economic of subsistence. In doing so, he refers the farming village as a peasant society, and so does the fishing village. He then argues that the peasant family is a unit of consumption and production, in which they produce and consume to meet subsistence at the minimum. At the same time, they struggle for the subsistence in the context of shortage of land, capital and outside employment opportunities. Scott, J. [8] also mentioned that labor is often the only factor of production and he/she may move into labor absorbing activities with low return until subsistence demands are met. This may mean that peasant may not switch crops or techniques, or market if they are not certain about the return, and a small drop in production can have disastrous effects on the survival of the households. This concern with subsistence and security is called the 'safety first' principle which means peasants are adverse to risk and focus on avoiding drops, not on maximizing expected profits.

A common feature of many peasant societies is the communal management. This promotes a 'shared 
collectivity' and a strong village identity. This identity in turn promotes consensual decision making, controls internal conflicts and prevents individualistic focuses on gain thus dominating atomized capital society. Community identity limits and controls differences in wealth among peasants by pressuring the wealthy to put any surplus into feast or other village benefits. When demands on village resource increase, there is an internal capacity to share resources by village redistributive mechanisms through such techniques as labor exchange which spreads the available work as far as possible. A village thus strives to guarantee its members some basic livelihood with the confine of community. The minimum formulation was that the elites must not invade the subsistence reserve of poor people; its maximal formulation was that elites had a positive moral obligation to provide for the maintenance needs of their subjects of dearth [8]. Introduction of new techniques that could yield more is often not taken by small farmers in bad year; they would face a subsistence crisis. Any act from Government, Company and rich people that threaten the subsistence security would result in resistance from small peasants.

As opposes to the 'moral economy', Popkin, S. [9] uses the concept of the political economy to argue against the concept of 'moral economy' that peasant competes over the resources for their owned interests. Some peasants do not revolt even when face with server subsistence crisis, but in return, they develop further strategy to compete with their rivals through cooperating with powerful groups. The subsistence crisis-short term and long term-complicates the guarantee for the welfare of the villager members. Given these uncertainties, peasant will rely on private, family investments for their long-run security and that they will be interested in short-term gain vis-à-vis village. They will attempt to improve their long-run security by moving into a position with higher income and the variance. Economic conflicts over advancement to more secure position are therefore inevitable within the village.

Whenever there is a collective action to produce public goods for the welfare or the assurance of the peasant society, individuals may calculate they are better off not contributing. As long as they cannot be excluded from the goods, there is the potential for free-riders, individuals who do not contribute to the provision of goods because they believe they will receive the gain or security even if they do not participate [9].

In addition, the patron-client relationship is changeable, renegotiable and shiftable in accordance with consideration of power and strategic interaction among individual. The dyadic nature of the relationship is not inherent, but is a matter of the ability of the lord or patron to individualize relations and prevent the collective bargaining. This, in return, means that resources of the patron will be invested, not only to improve the security and subsistence of the clients, but to keep relations dyadic and prevent the client's acquisition of any skills that might lead to different balance of power [9].

The territorialization of resources complicates the peasant's economic of subsistence and the political economy. The territorialization has led to the increase of the state control over individual and group of people over the access and use of resources $[10,11]$. The territorialization intensifies the political economy of resources uses. This has led to the politics of inclusion and exclusion, and resource conflicts as well as competing cooperation [12].

The globalization has brought the transnational companies close to communities and resources, and exposed them to the global economies where resources are extracted from local villages to serve the globe at large. The globalization increases the de-territorialization of the global economy, where the global trade is increasing borderless [13, 14]. The transnational companies invade local communities and compete for resources [15] and increases pressures on 'everyday geography' of the Global South. People in 
the South view the globalization as a big train coming to them, and they have to decide whether they stand on the railroad to stop the train or they jump into the train and travel along with it [16].

This paper discusses the political economy of fishing villages in the Tonle Sap Lake. It reviews the economic of subsistence of fishing villages in the Tonle Sap Lake and the changes happen in the Lake how it affects fishing villages and the way they deal with access to resources. Under the decline in resources in the Tonle Sap Lake, actor plays out a politics to access and maximize the resource exploitation for their short-term gain and leave the question of sustainability unanswered. In this circumstance, the political economy takes the form of patron-client relationship between fishing communities and powerful people including officials, commercial fishing operators and fish trader who could guarantee the access to resources and marketing their product. It is important to deepen and widen the understanding the relationship between the resource changes and the politics of resource uses. First, the paper reviews the economics of subsistence of fishing communities through examining communities who use resources and sharing it. Second, it examines the changes in resources and the changes in practices of fishing villages in the Tonle Sap Lake. Two case studies in the Tonle Sap are presented to illustrate the changes in resources and the changes of human interaction over resources and communities. Third, the paper studies the political economy of fishing villages in the Tonle Sap Lake in relation to access to resources and trading the resources.

For this study, two different communities in the Tonle Sap Lake were selected for in-depth study of the political economy of fishing villages: (i) Kampong $\mathrm{La}-\mathrm{a}$ land-based village in Pursat Province; and (ii) Kampong Phluk - a water-land based community located in Siem Reap Province. Qualitative and quantitative methods were used for data collection and analysis, spanning the household community, and provincial/national level. Participatory research methods included (a) observation; (b) focused-group discussion on fishing in each fishing villages, the fishing gears used by fishers in different fishing villages, the household status in each fishing community - the poor, the poorest, the medium and the rich; and the relationship of individuals with different fishing groups; and (c) the quantities methods included a household survey of 94 households. For the household survey, the study was particularly interested in the household uses of fishing gears in different fishing villages, the fish catch and the household status and the social relations in fishing. The authors also use the SPSS to support our analysis and the findings were shared with community members and some key government officials.

\section{Traditional Form of Rice-Fish Economy of Communities in the Tonle Sap}

\subsection{The Types of Communities in the Tonle Sap Lake}

Communities in the Tonle Sap Lake are classified into three different groups: 'land-based', 'water-based' and 'land-water based' communities [6]. The "land-based community" is a community where villagers are engaged in farming and less in fishing depending on the distance to the water body of the lake [17-19]. Moreover, the "water-based community" refers to floating village, where fishing is a primary occupation. The third group of communities is the "water-land based community", where the community is physically located in water for six months and on land for another six months.

\subsection{The Water-based Community}

The water-based community is defined as a community where people build their houses on water or the water house. The water house floats on water year round, and many water houses form a "floating community" [5]. A floating community floats and moves from one location to anther, depending on water level, for instance, Anlogn Raing or Kampong 
Loung communities float and move approximately 5-7 $\mathrm{km} / \mathrm{year}$ [6], and based on a village survey in the Tonle Sap Lake, the study identifies 53 floating villages in the Tonle Sap Lake, having similar characteristics with Anlong Raing and Kampong Loung. These floating villages are located in 10 districts in five provinces. Each "floating community" has a unique "cycle of movement and settlement" based on the rising and falling of the Lake water. Floating community consists of many floating houses, classifying into four different types: boat houses, ferry floating houses, bamboo rafting floating houses and pen floating houses. Each of these types has its own characteristics and tells the household status in the village.

\subsection{The Water-land based Community}

Water-land based community is a community where people live six months on land and six months on water in the Tonle Sap Lake. The house is built on the stilts about 6-8 $\mathrm{m}$ above the ground, standing in water for six months and another six months on land. In the dry season, water recedes the lake and the whole village is on land. However, in the wet season, water from the Mekong flows into the Lake and floods the whole village. The individual house becomes an "individual island" [20]. The water level rises almost up to the floor of the house-about 6-8 $\mathrm{m}$ high from the ground. The house does not alter the location, although the community experiences two extreme environments-flooding and drying conditions. Thus, this community is called a "permanent stand-stilt community". Many permanent stand-stilt communities are located in Siem Reap, Bantey Meanchey and Kampong Chhnang, estimating at about 36 stand-stilt communities, home to about 5,527 households (Table 1).

\subsection{The Land-based Community}

The land-based community is a community where people settle on land and the rise of water from the Tonle Sap Lake does not submerge the village's area. Most of these communities are situated in the highland areas above $6 \mathrm{~m}$ above sea level (asl) [2, 21]. People living in the land-based community is engaged in farming, but supplementing their incomes by fishing, depending on how near the village to the water body. They cultivate rice as a primary occupation, but fishing as a secondary job.

About 948 villages in the Tonle Sap floodplain are identified as land-based communities, which are home to about 0.8 million people (Table 1). According to Rab, M. A. et al. [17], land-based communities are those communities with at least 80 percent of households engaged in farming. However, fishing is also a key activity of most land-based communities, but the decree of fishing among villages depending on the distance to the lake and water body. Rab, M. A. et al. [17] call the community engaging both in farming and fishing as a "farming-cum-fishing". The survey of 270 households in Kampong Chhnang and Siem Reap provinces between 2003 and 2004 indicated that about 66 percent of fishing-cum-farming households fished all year round [22]. Hori M. et al. [22] examined

Table 1 Typology of communities by province in the Tonle Sap Lake.

\begin{tabular}{|c|c|c|c|c|}
\hline Province & $\begin{array}{l}\text { No. of community } \\
\text { fisheries }\end{array}$ & $\begin{array}{l}\text { Membership } \\
\text { list }\end{array}$ & $\begin{array}{l}\text { By-law and } \\
\text { regulation }\end{array}$ & $\begin{array}{l}\text { Area } \\
\text { agreement }\end{array}$ \\
\hline Siem Ream & 22 & 22 & 22 & 21 \\
\hline Kampong Thom & 30 & 30 & 30 & 30 \\
\hline Kampong Chhnang & 52 & 52 & 52 & 52 \\
\hline Pursat & 27 & 26 & 25 & 25 \\
\hline Battambang & 38 & 38 & 38 & 37 \\
\hline Bantey Meanchey & 6 & 4 & 4 & 2 \\
\hline Total & 175 & 172 & 171 & 167 \\
\hline
\end{tabular}


the significance of fishing to farmer-cum-fisher communities in Srey Rangit and Svay Ear in Chamnakroun commune, Stung district in Kompong Thom province. This study found that almost all households conducted rice cultivation and $75 \%$ of them are engaged in fishing. Fishing is important income sources for households and supplements to rice production [22].

Rice and fish is the backbone of the Khmer Society. Traditionally, rice is cultivated by land-based community, and fish is caught by water-based and land-water based communities, name after the fishing community. Every year, after the rice harvest and during the peak fishing season, farmer travelled to the river with a sack of rice to barter fish with rice. Similarly, fisher prepared fish to barter fish for rice. They met once a year at Kampong (landing area near to the river) to exchange their produces, especially fish and rice [23, 24]. This is a 'rice-fish economy' of communities in the Tonle Sap Lake.

At present, the rice-fish economy is transformed due to the introduction of the market economy. The barter of rice for fish is replaced by buying and selling of fish and rice in market places. The relationship between farmer and fisher is evolved through the process of exchange in market system. The market economy is facilitated by middlemen while farmers and fishers interact via the middlemen.

\section{Rice-Fish Economy of Community in Tonle Sap}

People from land-based community who cultivate rice is called as 'neak leu' and fish is caught by fisher or 'neak tonle' from water-based and land-water based communities. 'Neak leu' and 'neak tonle' consume both rice and fish, where rice provides the carbohydrate fuel for metabolic energy and fish provides the specific fatty oils that are mandatory constituent for organ development and function [24]; and thus, they exchange rice and fish as their backbone of community production.
Rice accounts for at least 68 percent of all Cambodian caloric intakes. This represents an annual per capita consumption, estimated at 151-200 kg per person/year or about 600-700 g a day/person [24]. At the same time, Cambodia is a fish-eating country - people catch fish, process fish and consume fish. Fish is consumed with rice, and it is consumed freshly or processing; and rice and fish is a popular food for majority of Cambodians [23, 24].

The main trading commodity of fishing community is "fish" and farming community is "rice" [23]. Rice and fish is exchanged since immemorial times in the Lake, and it has shaped the culture and practices of rice-fish economy in the Khmer Society [25]. The 'rice-fish' economy is a bartering economy of "neak leu" and "neak tonle". The 'bartering economy' depicts the 'social relation' than the economy itself that binds "neak leu" and "neak tonle" together beyond the village boundaries. "Neak leu" is primarily engaged in farming as a "primary occupation" in which rice is cultivated as a main food element, but fish is supplemented through rice-fish bartering. "Neak tonle" is primarily engaged in fishing as a "primary occupation", and fish is not the only main food item, but they also need "rice" [23, 24, 26].

The 'bartering economy' between farming (neak leu) and fishing communities (neak tonle) was based on two local systems namely "dor" (exchange) and "bondak" (pay rice in an installment). "Dor" means "I give your fish; you give me rice at the same time." However, "bondak" means "you take my fish now and you give me your rice paddy in the next harvest season" (per comm. with Sounthy, September 2015). People used their "local scale" to measure the rice and fish in the "dor" and "bondak". For "dor" (exchange), one kilogram of fermented fish (sour fermented fish or "prohok") is equal one "tao" of rice paddy (One tao is $12-15 \mathrm{~kg}$ of paddy rice), but for "bondak", one kilogram of sour fermented fish was equal 1.5 "tao". In the "dor" business, three "chongkak" of smoke fish (one chongkak has five fish) is equal one "krolor" of 
rice paddy ( 0.5 "tao"), and 2-3 pieces of a dry fish was one "kralor" of rice paddy. This practice was carried out before 1970s (per comm. with group of villagers in Kampong La, February, 2015).

The fresh fish is generally available from December to March. In this period, many rural Cambodians complete their rice harvest, and after rice harvest, rural Cambodians, especially farmers from land-based communities far away from the Lake went to 'Tonle' (River) to barter rice for fish [24, 27, 28]. During the peak fishing season (December to February), farmer travelled to Tonle (river) to barter fish to make "prohok" and they brought it back home for foods for the entire year. Such migration of Khmer farmers searching for "prohok" happened since the Angkor Empire. Baradat [23] described amazing facts about how Khmer farmers traditionally travelled from home villages in the direction to Tonle Sap Lake searching for "prohok". In 1926, there was 280 Oxcarts of Khmer communities living in Thailand travelled across the political boundary to the Tonle Sap Lake to make "prohok" for their food, and before 1907 when Battambang was still annexed to Thailand, Mr. Baradat counted 4,000 to 10,000 Khmer Oxcarts from Siam (Thai of Khmer origin) moving from Battambang and Surin provinces to the Tonle Sap Lake for "prohok". Such movement for "prohok" was significantly reduced after 1936 when crossing border became more stringent. But such Khmer culture is still preserved until today. About thousands ton of "prohok" including fresh fish from the Tonle Sap Lake has been exported to Thailand every year to supply to the Khmer ethnic minority [23, 29].

Indeed, fish is not abundant for year round (May to October), fish production reaches high peak in the dry season which last for about 4 months and decrease sharply during the wet season. Beside, fish production is not proportionally distributed throughout the region, and the highest production is derived from the Tonle Sap Lake while the lower output occurs in upland area far remote from the Tonle Sap Lake [23]. Moreover, most Khmer farmers are busy during the wet season and have no time to go fishing. So to maintain food requirement for a year cycle, Khmer communities have to work out how to preserve fish for long use. "Prohok" is an example of Khmer culture in fish processing which are treated with great delicacy during the farming season $[23,24,30]$. "Prohok" is made of fish and it is kept for the household food for many months. The way in which Khmer people preserve fish for long time use is just a unique cultural phenomenon [23].

As an example, people from Kampong $\mathrm{La}$ are considered as a "neak leu". The exchange of rice and fish was done in Kampong La. Farmer from other villages such as from Chek Chau. Porkod came down with rice to exchange with fish at Kampong La with the fishers from Anlong Rainga and Kampong Prak villages who are considered as "neak tonle". In the old day, Kampong La was a landing area where people exchanged fish and rice in front of the Buddhist temple known as "wat Thkol". The river in front of the temple was deep, approximately 3-4 $\mathrm{m}$ in the dry season with the width of $25 \mathrm{~m}$. The river was navigable in both the dry and wet seasons, but nowadays, it is no longer navigable in the dry season, only part of river between Kampong La and the Tonle Sap Lake could be navigable (per comm. with group of villagers in Kapong La, February, 2015).

Fishers, from Anlong Raing and Kampong Prak, after bartering fish for rice, could not bring rice paddy back to their houses. Then, they built the rice storage within Kampong La. The rice was kept at the house of somebody they knew best in Kampong La. Those did not pay the full amount of rice were in dept for one season and fishers came back to collect the unpaid rice in the following season. The deal between "neak leu" and "neak tonle" was simple, based on a mutual interests and supports. It was done through a local system of 'equal exchange' based on a mutual trust, giving and getting at the same time, no commission charge, no intermediary agent, no cash involved and 
no institutional function. The 'equal exchange' serves as the basis for the structure of friendship and cooperation between farming and fishing communities (per comm. with group of villagers in Kampong La, February, 2015).

Similarly, people in Kampong Phluk are named as a 'neak tonle'. "Neak tonle" fishes and takes fish to barter for rice with "neak leu" from Rolous, Kandek, Meanchey and Samrong communes in Prasat Bakong and Danrun and Kchas communes in Sotr Nikum District, Siem Reap Provine. At the same time, "neak leu" from Meanchey and Samrong, Danrun and Kchase communes come down to Kampong Phluk and grow munbean in the area close to the Tonle Sap Lake. About 321 ha in Kampong Phluk was cultivated munbean for a long time by people from Meanchey and Samrong communes from Prasat Bakong District, and Danrun and Kchas communes from Sotr Nikum District since 1970.

The social relationship of "neak tonle" and "neak leu" is deeply rooted in the "rice-fish economy". This relationship allows "neak tonle" and "neak leu" to acquire foods they need to feed their household members. This makes "neak tonle" and "neak leu" two components of one system of the Tonle Sap Lake, each functions in accordance with the others. A form of 'dependency' was established and interrelated between "neak leu" and "neak tonle" to share their resources.

\section{Territorialization of the Tonle Sap Lake}

The territorialization of the Tonle Sap Lake into different spaces has affected the resource usage, the relationship between "neak leu" and "neak tonle", and the economy of fishing villages. The cancellation of fishing lot system, the designation of the Tonle Sap Lake as a biosphere reserves, the zoning of the protected flooded forest, and the development of community fishery have changed the way in which people access to resources in the lake.

By 2005, an estimated 412,205 ha of the fishing areas, covering six provinces around the Tonle Sap Lake had been territorialized into 175 "community lots" around the Tonle Sap Lake. The "community lot" is technically and politically called a "community fishery". Some 175 community fisheries are home to 61,613 households living in 361 villages in six provinces around the Tonle Sap Lake, of which 38 percent of them are dependent on fishing as a primary occupation, and the rest are fishing as well as farming for the livelihoods (Table 2).

Each Community Fisheries (CF) is demarcated with a boundary and map is drawn to differentiate one $\mathrm{CF}$ from the others. Members of one CF are tagged to exclude them from the other CFs. The community fishery is established on the public fishing area and 71,395 fishermen are a member of 175 community fisheries, of which man represents 55 percent of the total members of these community fisheries. Members of the CF fish subsistence only, using small-scale fishing gears, and those, who are not a member of CF, are not allowed to fish inside the $\mathrm{CF}$ areas, unless they get permission from $\mathrm{CF}$ committees. Among the CFs in the Tonle Sap Lake, 172 CFs have a list of

Table 2 The community fisheries around the Tonle Sap.

\begin{tabular}{|c|c|c|c|c|c|c|c|}
\hline Province & No. of village & $\begin{array}{l}\text { No. of } \\
\text { household }\end{array}$ & $\begin{array}{l}\text { No. HH } \\
\text { depending } \\
\text { on fisheries } \\
\end{array}$ & $\begin{array}{l}\text { CF area } \\
\text { (ha) }\end{array}$ & $\begin{array}{l}\text { No. } \\
\text { sanctuary }\end{array}$ & 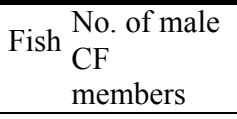 & $\begin{array}{l}\text { No. of female } \\
\text { CF } \\
\text { members }\end{array}$ \\
\hline Kampog chhnang & 51 & 6,470 & 0 & 42,071 & 0 & 6,523 & 6,349 \\
\hline Siem ream & 129 & 21,698 & 15,052 & 90,728 & 1,232 & 11,852 & 9,622 \\
\hline Pursat & 52 & 5,808 & 619 & 85,712 & 155 & 5,950 & 4,910 \\
\hline Kg. thom & 54 & 4,631 & 5,232 & 40,994 & 201 & 4,852 & 4,154 \\
\hline BTB & 62 & 20,197 & 2,402 & 144,506 & 157 & 8,964 & 5,808 \\
\hline $\mathrm{BMC}$ & 13 & 2,809 & 67 & 8,194 & 33 & 1,358 & 1,053 \\
\hline Total & 361 & 61,613 & 23,372 & 412,205 & 1,778 & 39,499 & 31,896 \\
\hline
\end{tabular}


Table 3 Community fishery in Tonle Sap by province.

\begin{tabular}{lllll}
\hline Province & $\begin{array}{l}\text { No. of community } \\
\text { fisheries }\end{array}$ & $\begin{array}{l}\text { Membership } \\
\text { list }\end{array}$ & $\begin{array}{l}\text { By-law and } \\
\text { regulation }\end{array}$ & $\begin{array}{l}\text { Area } \\
\text { agreement }\end{array}$ \\
\hline Siem ream & 22 & 22 & 22 & 21 \\
Kampong thom & 30 & 30 & 30 & 30 \\
Kampong chhnang & 52 & 52 & 52 & 52 \\
Pursat & 27 & 26 & 25 & 25 \\
Battambang & 38 & 38 & 38 & 37 \\
Bantey meanchey & 6 & 4 & 4 & 2 \\
Total & 175 & 172 & 171 & 167 \\
\hline
\end{tabular}

membership, which is important for members to fish inside the CF areas (Table 3).

The territorialization of Tonle Sap has led to delimitation of the boundary of fishing areas into the fish conservation and the public fishing areas. The boundary and the designation of spaces such as fish conservation, public fishing areas, and community fisheries exclude and include both "neak tonle" and "neak leu". Recently, the public fishing area is further territorialized into community fisheries in which the community fisheries exclude "neak leu" from fishing inside the community fisheries. Thus, it deteriorates the relationship of "neak leu" and "neak tonle", affecting the tradition of rice-fish economy. The following section discusses the change in the relationship of "neak leu" and "neak tonle" in a great detail.

\section{Market Economy of Farming and Fishing Community in the Tonle Sap Lake}

The territorialization of the Tonle Sap Lake aims at increasing economic development, poverty reduction, and conservation fisheries and biodiversity. This has turned the relationship of sharing the resources into the competition. By territoiralization, "neak leu" and "neak tonle" were forced to adopt himself the monetary economy as state imposed on "neak leu" and "neak tonle" the demand duties, and rights. Market was organized where fishers and farmer could sell their produces. In buying and selling, farmer and fisher need to have cash; without cash, they are excluded from the market system. Therefore, fishers and farmers force themselves to sell either fish or rice to middlemen to get cash in order for them to enter into the market economy.

Fish and rice have to be sold at the market place, no longer at "kampong" (landing site), and often small farmer with 2-3 buskets of paddy rice and small fishers with few kilogram of fish find themselves uneasy to enter into the market and it is costly to travel from village to market in the district center, about 10-20 $\mathrm{km}$ from their villages. Instead, middlemen come to villages, acting as an arm of the market, extending the market from the district or provincial centers to farmers and fishers. Middlemen take fish from fishers and then sell it to farmers and middlemen buy rice from farmers and then sell them to fishers.

For instance, Kampong La and Anlong Raing is geographically located $12 \mathrm{~km}$ away from each other, and socially Kampong $\mathrm{La}$ is a farming-cum-fishing village located on upland area of the Tonle Sap floodplain, while Anlong Raing is a floating village located on water in the Lake. About 2-3 middlemen from Kampong La buy rice from villagers and supply household materials to farmers including fish, salt, soap, fertilizers etc.. Farmers could take materials from middlemen in advance and repay at the harvest time or they can buy and hand over cash at the same time. In Anlong Raing, there are three fish traders that buy fish daily from fishers and bring to Kampong Loung (district market) every 2-3 days, and there they sell it to farmers and other people.

Given the interplay of market economy in the "buying and selling" fish and rice, the price of rice and fish is not determined by farmer or fisher, but by 


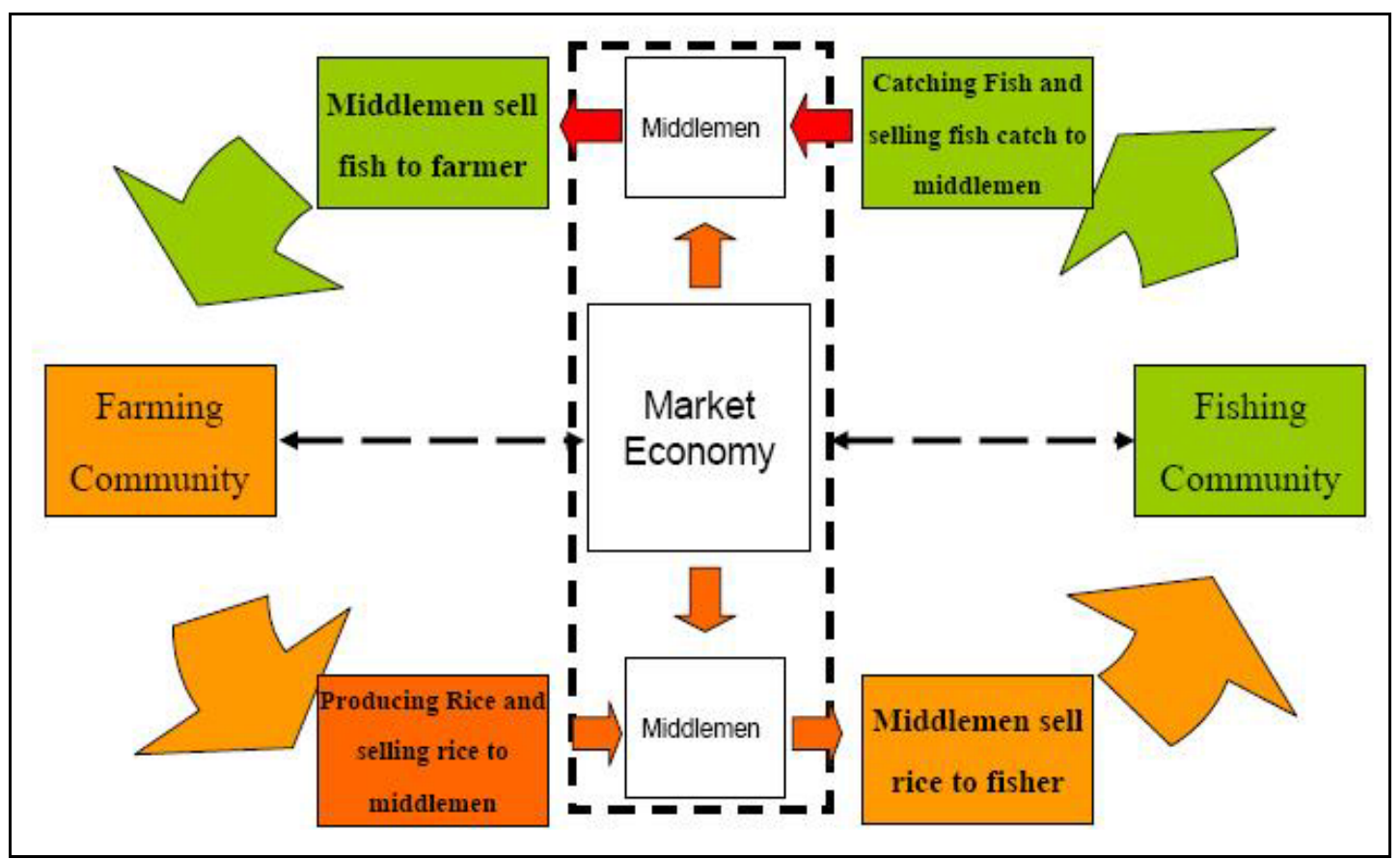

Fig. 1 Relationship of farming and fishing communities in the market economy.

middlemen. Farmer and fisher are free from price setting but a price taker, and so, they have a little say over their few kilogram of rice and fish, and less power to bargain it as always worry about spoiling the fish or rice, and thus, forcing to sell their produces even in low price. Through this, it turns the relationship of "neak tonle" and "neak leu" into competition over the resources. In the process, farming community reduces the dependency on fishing community in supplying them a fish. Instead, farmers have transformed themselves into fishing and fish along farming to feed their households. At the same time, fisher encroaches on the flooded forest areas to clear land for agriculture and fish along farming to support their families in the context of competition.

In the changing pattern, each community turns to depend on market to provide them resources needed to support their livelihoods. As a result, the economy of communities is both rice and fish, different from the rice-fish economy in the old day when "neak leu" and "neak tonle" live dependent on each other, while the market economy separates "neal leu" from "neak tonle" and in return, "neak leu" and "neak tonle" seeks to do both farming and fishing.

\subsection{Rice-Fish Economy of Farming Community-A Case Study from Kampong La}

The cooperation between "neak leu" and "neak tonle" has turned into competition and the rice-fish exchange is no longer applied as it was. Rather, farmer and fisher compete for the declining resources. "Neak leu" turns themselves into doing both farming and fishing, and fishing is geared toward commercialization. This transformation has happened due to the fact that fisheries become a commercially high value, and engaging in fishing provides farmers with two sources of benefit stream. By doing both farming and fishing, they are no longer 'dependent' on the supply of fish' from fishing communities. The competition between "neak leu" and "neak tonle" takes the form of upgraded and increased number fishing gears, fishing longer time, and claiming or fishing in the same fishing grounds owned by the Anlong Raing Fishing Communities. To study the "rice-fish economy", the study looks at the farming and fishing economy of Kampong La. 


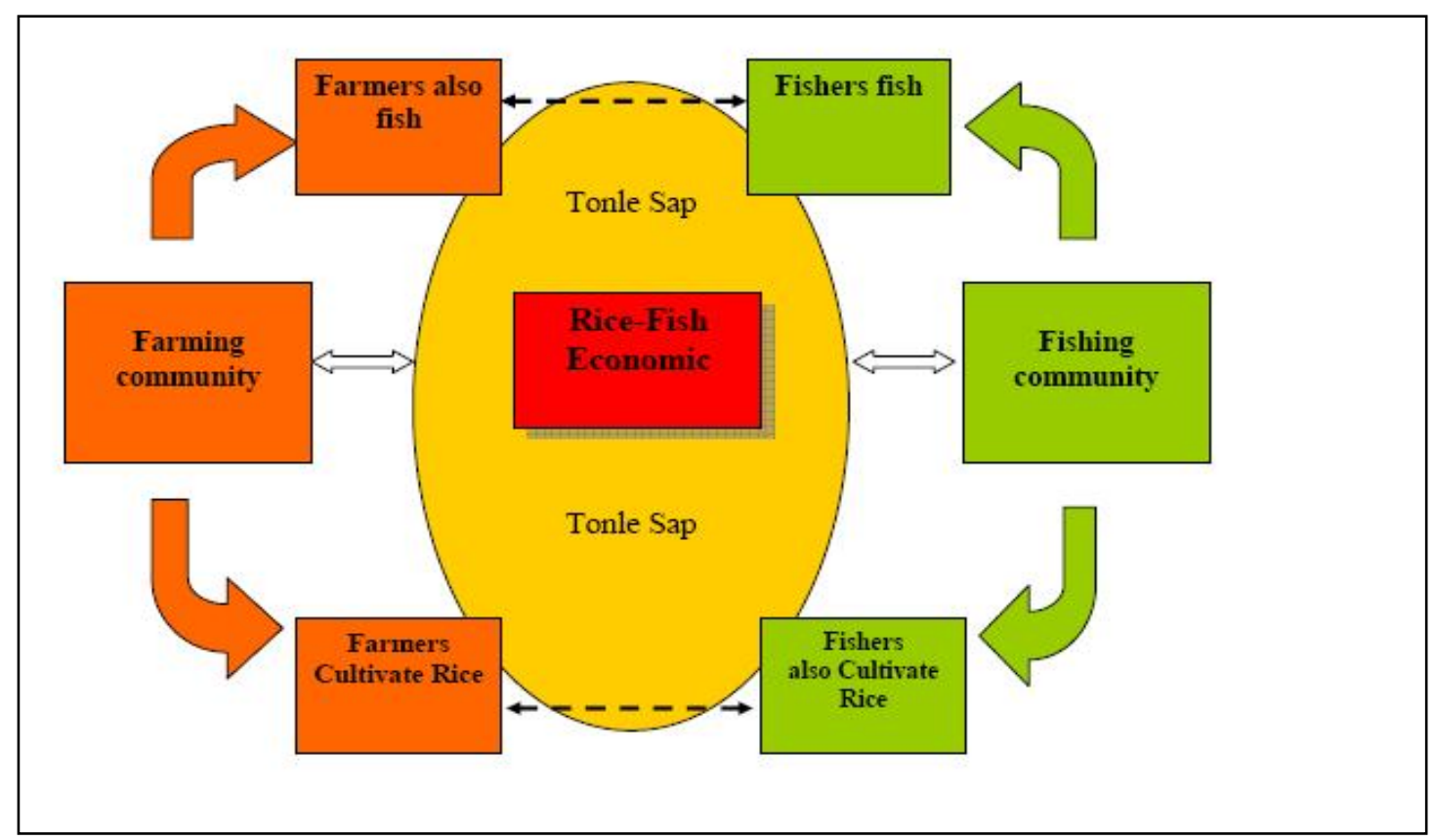

Fig. 2 Dual economy of fishing communities in Tonle Sap.

\subsubsection{Rice Farming Economy of Farming Village}

Kampong La is home to about 189 households; of which about 65 percent of households are nuclear families while 4 percent are extended families. A notable point is the high percentage of female headed households: women head 29 percent of household in Kampong La and about two percent of household is headed by male as a widower [31]. Kampong La is a farming village; with a majority of households relies on farming as the main economic activity. However, Kampong La is dependent on Anlong Raing to provide them a fish, but returns rice to Anlong Raing. Thus, for Kampong La, farming is the primary job and land is the main household assets that generate food and income for households.

Lands belonging to Kampong La were estimated at about 874 ha, classifying into housing area, rice field, water forest areas and uncultivated land [32]. In 2015, only 76 percent own agricultural lands and the landless families grow significantly to about 24 percent. About 21 percent of households own 0.5-1 ha of farmland; and 26 percent own 1-2 ha. However, 16 percent and nine percent of household own 2-4 ha and 4-7 ha respectively. Each household landholding was scattered in low-lying areas, which is called a "srekrom" (deep water rice field/floating rice field) and middle-lying areas which is called "sreleu" (rainfed lowland rice field).

Sreleu and Srekrom yield differently. Different rice field in "sreleu" and "srekrom" yields differently too. The study also records the rice yield produced by the farmland owned by each household. Based on these, 'sreleu' yields totally $102,680 \mathrm{~kg}$ from 108 hectares and 'srekrom' yields totally $174,020 \mathrm{~kg}$ from 188 hectares. Based on this, the yield is estimated at about $950 \mathrm{~kg}$ per hectare-relatively low compared with the rest of Cambodia.

\subsubsection{Fishing Economy of Kampong La}

At present, the rice-fish exchange between Kampong $\mathrm{La}$ and Anlong Raing is broken. As population increased and the increase in landless population, fishing is significantly increased in Kampong La. Among total households, about 35 percent are engaged in both farming and fishing. For these households, fishing is the secondary occupation. However, 9 percent of the households in Kampong La rely on fishing as a main occupation, given their lack of cultivated land. Totally, throughout the village, 44 
percent of household, both with land and landless, are engaged in fishing.

Fishing is about "catching enough" fish to feed household members. The present fish catch is perceived to be declined. However, fish catch is varied between high or peak and low fishing seasons. The high fishing season starts from October to May, defined as an "open fishing season" and the low fishing season started from June to October. During the peak fishing season, the fish catch is also increased compared to the normal fish catch. About 60 percent of interviewed households report the increased fish catch during the peak fishing season to $5-10 \mathrm{~kg} /$ day. This is happened between December and January or February. However, the fish catch is not homogenous between household, depending on labors employed in fishing and fishing gears use during this period by each household.

During the low fishing season, it is estimated that 40 percent of households report household fish catch of $0.2-2 \mathrm{~kg} /$ day. About 13 percent of interviewed households reports the daily fish catch of $3-5 \mathrm{~kg} /$ day, and only 11 percent report the household catch of 7-20 $\mathrm{kg}$ a day. The fishing effort has been increased due to the decline in household catches per unit of fishing efforts. There is an increase of "mouths" in the households to eat food; therefore, there is a need to increase fishing effort to ensure enough foods. On the other hand, fishing household relies merely on fishing and lack of alternatives makes them hard to get away from fishing. However, in both high and low fishing seasons, an average, the daily household fish catch is estimated at about $2-5 \mathrm{~kg} /$ day.

As indicate above, villagers in Kampong La fish mainly for consumption, but does not mean they do not sell fish. In an interview of 45 households, within the present fish catch (2-5 kg/day), 44 percent of interviewed households report they eat $0.5-1 \mathrm{~kg}$ of fish they caught. However, the amount of fish consumption per household is varied from household to household. About 18 percent of interviewed households consume $1.5-2 \mathrm{~kg}$ of fish catch every day, 11 percent consume $2.5-5 \mathrm{~kg}$ a day and 7 percent of households consume all fish they caught. This suggests that the fish consumption varies from household to household, depending on the household size. Even these differences, based on this study, the majority of households consume $0.5-1 \mathrm{~kg}$ a day. The majority of the households have a household size of five members. All households both fishing or non-fishing households consume fish every day, and fish become a common food dish in the household (Table 4).

It is of course people sell fish that they catch to fish traders, to villagers in the village and exchange with rice. In general, people trade a high value fish and eat the low value fish. This is because they need the "cash". The cash they earn will be used for purchasing clothes, salt, rice for those purely fishing households, fishing equipments and medicines for their health. Among interviewed households, 35 percent report that they sold $1.5-3 \mathrm{~kg}$ of their catches, and only 9 percent and 13 percent sold $3.5-4 \mathrm{~kg}$ and $5-10 \mathrm{~kg}$ of their catch respectively. This suggests that majority of households

Table 4 Fish catch by fishers in Kampong La by fishing season.

\begin{tabular}{llllll}
\hline \multicolumn{3}{c}{ The fish catch in the peak fishing season } & \multicolumn{3}{c}{ Fish catch in the low fishing season } \\
\hline Fish catch & $\begin{array}{l}\text { No. household } \\
\text { interview }\end{array}$ & Percentage & Fish catch & $\begin{array}{l}\text { No. household } \\
\text { Interview }\end{array}$ & Percentage \\
\hline $5-10 \mathrm{~kg}$ & 27 & 60 & $0.2-2 \mathrm{~kg}$ & 18 & 40 \\
$11-20 \mathrm{~kg}$ & 4 & 8.89 & $3-5 \mathrm{~kg}$ & 6 & 13.33 \\
$21-30 \mathrm{~kg}$ & 1 & 2.22 & $7-20 \mathrm{~kg}$ & 5 & 11.11 \\
$31-40 \mathrm{~kg}$ & 1 & 2.22 & - & - & - \\
$41-50 \mathrm{~kg}$ & 1 & 2.22 & - & - & 35.56 \\
No response & 11 & 24.44 & No response & 16 & 100 \\
Total & 45 & 100 & Total & 45 & - \\
\hline
\end{tabular}


Table 5 The fish catch and the fish consumption by household.

\begin{tabular}{llllll}
\hline & \multicolumn{2}{c}{ Average household fish catch } & \multicolumn{3}{c}{ The fish consumption on a daily basis } \\
\hline $\begin{array}{l}\text { Category of } \\
\text { fish sale }\end{array}$ & $\begin{array}{l}\text { No. of } \\
\text { household }\end{array}$ & Percentage & Catch by category & $\begin{array}{l}\text { No. of } \\
\text { household }\end{array}$ & Percentage \\
\hline $0.5-1 \mathrm{~kg}$ & 4 & 8.89 & $0.2 \mathrm{~kg}$ & 1 & 2.22 \\
$1.5-3 \mathrm{~kg}$ & 16 & 35.56 & $0.5-1 \mathrm{~kg}$ & 20 & 44.44 \\
$3.5-4 \mathrm{~kg}$ & 4 & 8.89 & $1.5-2 \mathrm{~kg}$ & 8 & 17.78 \\
$5-10 \mathrm{~kg}$ & 6 & 13.33 & $2.5-5 \mathrm{~kg}$ & 5 & 11.11 \\
- & - & - & Eat all & 3 & 6.67 \\
No answer & 15 & 33.33 & No answer & 8 & 17.78 \\
Total & 45 & 100 & Total & 45 & 100 \\
\hline
\end{tabular}

sell 1.5-3 kg of their catch and the rest is for consumption (Table 5).

In summary, the daily fish catch is estimated at 2-5 $\mathrm{kg}$ a day. In this total catch, people consume $0.5-1 \mathrm{~kg}$ a day, representing 20-25 percent of the total catch, and sell $1.5-3 \mathrm{~kg}$, or $60-70$ percent of the total fish catch. People keep 5-20 percent of the catches for fermentation and "prohok". The salty-dry fish and "prohok" is kept for food during the rice transplanting season and the low fishing season.

5.2 Fish-Rice Economy of Fishing Community in Tonle Sap-A Case Study in Kampong Phluk Community

Fishing community is diversifying their economic activities given the decline in fish catch, and many of them have turned to do both fishing and farming. This is clearly illustrated from the case study of Kampong Phluk - a fishing commune located in the Tonle Sap Lake. Kompong Phluk administratively covers area of 14,249 hectares. It is classified into flooded forest area (7,328 ha), cultivated area (1,409 ha), open water (5,378 ha), swamp area (118 ha) and housing areas (14 ha). In the wet season, the whole area of Kampong Phluk is under water, but it is dry out in the dry season. Thus, fishing is the primary occupation of the households in Kampong Phluk [33, 34].

\subsubsection{Fishing Economy of Kampong Phluk}

Kampong Phluk is home to 513 fishing households. About 94 percent of its population is engaged in fishing. Most of them claim that they fish for subsistence, using small-scale fishing gears. Among fishing households, about 34 percent is engaged in fish processing. Some households, accounting for 32 percent, practice a fish and pig raising. Fish raising is practiced based on the traditional know-how and the fingerlings are collected from the wild fisheries to adopt in the cage or pen known locally as a "Be". Pig raising is also a small-scale. Each household raises 2-3 piglets in a pen standing above the water in the Kampong Phluk River. The fish pen and the pig pen float in both the dry and the wet seasons.

About 25 percent of households in Kampong Phluk grow vegetable along the bank of the Kampong Phluk River. They grow vegetable mainly in the dry season for household consumption. In the wet season, there is no place they can growth vegetable given that all lands were submerged by flood. Moreover, some 12 percent of households in Kampong Phluk are engaged in petty trading which is called by a villager as a "lok chap hoy" or grocery. They sell many things including spices, sugar, salt, etc., which could supply villagers. Some other people in the village are engaged in service provision such as boat driving and motorcycle taxi, accounting for 11 percent of the households.

Fish catch varies between high and low fishing seasons. During the high fishing season, about 34 percent of the households catch 2-5 kg of fish/day, another 26 percent caught $5-10 \mathrm{~kg}$ a day and 20 percent catch $20-50 \mathrm{~kg}$ a day. During the same period in the last 5-10 years, 43 percent of the interviewed households indicate the level of fish catch of about $100-300 \mathrm{~kg}$ a day and 30 percent were $50-100 \mathrm{~kg}$ a day (Table 6). This suggests that the household daily fish catch 
Table 6 Livelihood activities by wealth group.

\begin{tabular}{|c|c|c|c|c|c|c|c|c|}
\hline \multirow[b]{2}{*}{ Household economy } & \multicolumn{2}{|c|}{ Thnot kambot } & \multicolumn{2}{|c|}{ Dei kraham } & \multicolumn{2}{|c|}{ Kouk kdol } & \multicolumn{2}{|c|}{ Total } \\
\hline & $\begin{array}{l}\text { No. } \\
\text { household }\end{array}$ & $\%$ & $\begin{array}{l}\text { No. } \\
\text { household }\end{array}$ & $\%$ & $\begin{array}{l}\text { No. } \\
\text { household }\end{array}$ & $\%$ & $\begin{array}{l}\text { No. } \\
\text { household }\end{array}$ & $\%$ \\
\hline Fishing & 150 & 100 & 133 & 93.01 & 129 & 89.6 & 412 & 94.28 \\
\hline Fish processing & 30 & 20 & 56 & 39.16 & 62 & 43.1 & 148 & 33.87 \\
\hline Raising fish and pig & 66 & 44 & 41 & 28.67 & 31 & 21.5 & 138 & 31.58 \\
\hline Growing vegetable & 36 & 24 & 10 & 6.99 & 62 & 43.1 & 108 & 24.71 \\
\hline Petty trading & 12 & 8 & 20 & 13.99 & 21 & 14.6 & 53 & 12.13 \\
\hline Others & 36 & 24 & 4 & 2.80 & 10 & 6.9 & 51 & 11.67 \\
\hline
\end{tabular}

Source: Ref. [33].

has declined during the high fishing season. The poor and the poorest fishing households are affected more than the others due to their lack of means of catching fish while the rich and the medium fishing household address the situation by upgrading fishing gears.

The low fishing season is between May and October. During this period, it is a "close fishing season". All fishing activities, except small-scale/family-scale, are prohibited, allowing fish to lay egg and grow. As many fishing households in Kampong Phluk engaged in fishing activities, efforts have been made to catch more fish and therefore, fishing activities are still carried on during the close fishing season. The present daily fish catch in the low fishing season is estimated at $1-5 \mathrm{~kg}$ a day.

However, the average fish catch per household 5-10 years ago was about 10-20 kg a day, constituting 32 percent of the interviewed households, and another 32 percent report the daily fish catch of $20-50 \mathrm{~kg} /$ day (Table 7). Thus, this suggests that the fish catch has declined, and therefore, raising the concern among fishers how to make enough foods and how to find an alternative livelihood.

\subsubsection{Farming Economy of Kampong Phluk}

As a decline in fish catch, fishing households in Kampong Phluk turns into farming as alternative, but face challenges in doing farming. About 1,114 ha ha of floodplain areas in Kampong Phluk is potential for the dry season and munbean farming. The dry season rice covers an area of 1,083 ha, while the munbean for 321 ha. People from Meanchey and Samrong communes of Prasat Bakong and Danrun and Kchas communes of Sotr Nikum District migrated down to the Lake during the dry season and cultivated the munbean in Kampong Phluk. At the same time, about 100-130 families from other communes namely Rolous and Kandek cultivate the dry season rice between January and April in Kampng Phluk [20, 33] (per.comm. with commune council, August, 2015).

The relationship between Kampong Phluk and farming communities such as Rolous and Kandek, farming communities has been broken. In return, farming community is no longer dependent on fishing community like Kampong Phluk to supply them fish. Instead, they encroach the fishing areas to fish even inside the newly defined community fisheries. Nowadays, the farming communities near the Lake become both farming and fishing communities, but Kampong Phluk remains a solely fishing community. Seeing this, the Kampong Phluk authority and households make an effort to retain the flooded land in the Kampong Phluk that cultivated by people from Rolous and Kandek. This has resulted in a conflict between them and this even make the relationship between them poorer.

In 2007-2008, villagers in Kampong Phluk envision the rice farming as an alternative livelihoods given the decline in fish catch. About 500 families from Kampong Phluk put the request to the Provincial Administration to turn 1,690 ha of flooded forest areas into the dry season rice (per comm. with Commune Councils of Kampong Phluk, August, 2015). The 
Table 7 The estimated household fish catch in the peak fishing season.

\begin{tabular}{|c|c|c|c|c|c|c|c|c|c|c|c|}
\hline \multicolumn{6}{|c|}{ Fish catch in a high fishing season } & \multicolumn{6}{|c|}{ Fish catch in a low fishing season } \\
\hline $\begin{array}{l}\text { At } \\
\text { present } \\
(\mathrm{kg}) \\
\end{array}$ & $\begin{array}{l}\text { No. of } \\
\text { respondent }\end{array}$ & $\%$ & $\begin{array}{l}5-10 \\
\text { years ago } \\
(\mathrm{kg})\end{array}$ & $\begin{array}{l}\text { No. of } \\
\text { respondent }\end{array}$ & $\%$ & $\begin{array}{l}\text { At present } \\
(\mathrm{kg})\end{array}$ & $\begin{array}{l}\text { No. of } \\
\text { respondent }\end{array}$ & $\%$ & $\begin{array}{l}5-10 \\
\text { years ago } \\
(\mathrm{kg})\end{array}$ & $\begin{array}{l}\text { No. of } \\
\text { respondent }\end{array}$ & $\%$ \\
\hline $2-5$ & 12 & 34.29 & $5-20$ & 3 & 13.04 & & & & $0.5-5$ & 2 & 9.52 \\
\hline $5-10$ & 9 & 25.71 & $20-50$ & 3 & 13.04 & $1-5$ & 28 & 77.78 & $5-10$ & 4 & 19.05 \\
\hline $10-20$ & 3 & 8.57 & $50-100$ & 7 & 30.43 & $5-10$ & 6 & 16.67 & $10-50$ & 13 & 61.90 \\
\hline $20-50$ & 7 & 20.00 & $100-300$ & 10 & 43.48 & $10-20$ & 2 & 5.56 & $50-100$ & 2 & 9.52 \\
\hline $50-120$ & 4 & 11.43 & & & & & & & & & \\
\hline Total & 35 & 100.0 & Total & 23 & 100.0 & Total & 36 & 100.0 & Total & 21 & 100.0 \\
\hline
\end{tabular}

reasons of doing this include the decline in fish catch, the encroachment of highlander into the flooded forest areas, taking land for agriculture, and the land speculation.

\section{Conclusion}

The Tonle Sap Lake is home to different types of communities - water-based, water-land based and land-based communities. Traditionally, these communities practiced a subsistence economy known as a rice-fish bartering economy in which farming community bartered the rice for fish with fishing community. The territorialization of the freshwater in the Tonle Sap Lake has led to commercialization of fisheries resources in which the fishing and farming communities compete for resources. The rice-fishing economy is substituted by a market economy in which the bartering economy is replaced by the buying and selling in which the close relationship between the farming communities and fishing communities is facilitated by the middlemen. To enter the market economy, fisher or farmer values their product in terms of cash, without cash, they are not able to enter into the buying and selling.

Given the dominance of the market economy in the Tonle Sap Lake, fishing and farming communities compete for resources. Fisher catches fish and sells fish to middleman and then they buy rice from middleman. Similarly, farming community cultivates rice and sells rice to middleman, and then buys fish from middleman. Middleman acts between farming and fishing communities. This has led to the fact that farming community is no longer dependent on fishing community to supply the fish they need. Instead, farming community goes to middleman to buy fish, but majority of them instead go fishing as well. The same as farming community, fishing community is no longer dependent on farming community to supply them rice, and thus, some fishers go farming by capturing the land for agriculture. Thus, farming and fishing communities practise both farming and fishing as a dual function.

The farming-cum-fishing community cultivates rice as a primary occupation and fishing as a secondary occupation, while floating and stand-stilt communities depend on fishing as a primary occupation. The later community catches fish and sells fish. As fish is declined, fisher depends more deeply on moneylender to provide them a loan without interest charge, but require fisher to sell fish to the moneylender cheaper than the market price. A series of interactions takes place between fisher and middleman as a series of middleman operates in fish trading in the Tonle Sap Lake, ranging from village middleman, mobile fish buyer, collective fish buyer and wholesale fish buyer. This forms the 'web of moy' in Tonle Sap.

\section{References}

[1] Kummu, M., Sarkkula, J., Koponen, J., and Nikula, J. 2006. "Ecosystem Management of the Tonle Sap Lake: An Integrated Modelling Approach." Journal of Water Resources Development 22 (3): 497-519.

[2] Keskinen, M. 2006. "The Lake with Floating Villages: Socioeconomic Analysis of the Tonle Sap Lake.” Journal of Water Resources Development 22 (3): 463-480. 
[3] Van Zalinge, N., Thouk, N., Touch, S. T., and Deap, L. 2000. "Where There is Water, There is Fish?" In Proceedings of Common Property in the Mekong Issues of Sustainability and Subsistence, 37-48.

[4] Keskinen, M., Kummu, M., Salmivaara, A., Paradis, S., Lauri, H., and Moel, H. 2011. Baseline Results from Hydrological and Livelihood Analyses: Exploring Tonle Sap Futures Study. Aalto University study.

[5] Sithirith, M., and Grundy-Warr, C. 2013. Floating Lives of the Tonle Sap. Thailand: Regional Center for Sustainable Development (RCSD), Faculty of Social Sciences and Chiang Mai University.

[6] Sithirith, M. 2011. "Political Geography of the Tonle Sap: Power, Space and Resources." Ph.D. thesis, National University of Singapore.

[7] Royal Government of Cambodia (RGC). 2006. Fisheries Reform Ministry of Agriculture, Forestry and Fisheries, Phnom Penh, Cambodia.

[8] Scott, J. 1976. The Moral Economy of Peasant: Rebellion and Subsistence in Southeast Asia. New Haven and London: Yale University Press.

[9] Popkin, S. 1979. TheRrational Peasant: The Political Economy of Rural Society in Vietnam. Berkeley, Los Angeles and London: University of California Press.

[10] Sack, Robert. 1986. Human Territoriality: Its Theory and History. Cambridge: Cambridge University Press.

[11] Vandergeest, P. and Peluso, N. 1995. "Territorialization and State Power in Thailand." Theory and Society 24 (3): 385-426.

[12] Vandergeest, P. 1996. "Mapping Nature: Territorialization of Forest Rights in Thailand." Society and Natural Resource 9: 159-175.

[13] Paasi, Anssi. 2003. A Companion to Political Geography. Oxford: Blackwell.

[14] Massey, D. 1994. Space, Place and Gender. Cambridge: Polity Press.

[15] Howitt, R. 2003. Rethinking Resource Management: Justice, Sustainability and Indigenous People. London and New York: Routledge.

[16] Rigg, J. 2007. An Everyday Geography of the Global South. London and New York: Routledge.

[17] Rab, M. A., Hap N., Ahmed M., Keang S. L., and Viner K. 2005. Socioeconomics and Values of Resources in Great Lake-Tonle Sap and Mekong-Bassac Area: Results from a Sample Survey in Kampong Chhnang, Siem Reap and Kandal Provinces. Penang, Malaysia: World Fish Center,.

[18] Hap, N., Chuenpagdee R. and Kurien J. 2006. Livelihood Importance and Values of Tonle Sap Lake Fisheries. Phnom Penh: Inland Fisheries Research and Development Institute.

[19] Cambodia Development Resource Institute (CDRI). 2007.
We are living with worry all the time: A participatory poverty assessment of the Tonle Sap. Phnom Penh: CDRI.

[20] Asia Forest Network (AFN). 2004. Flooded Forests, Fish and Fishing Villages, Tonle Sap, Cambodia. Bohol: AFN.

[21] Keskinen, M. 2003. "Socio-economic Survey of the Tonle Sap Lake, Cambodia." Master Thesis, Water Resource Library and Helsinki University of Technology.

[22] Hori, M., Ishikawa, S., Heng, P., Thay, S., Ly, V., Thuok, N., et al. 2006. "Role of Small-Scale Fishing in Kompong Thom Province, Cambodia”. Fisheries Science 72 (4): 846-854.

[23] Bonheur, N. and Lane B. D. 2002. "Natural Resource Management for Human Security in Cambodia's Tonle Sap Biosphere Reserve." Environmental Science and Policy 5 (1): 33-41.

[24] Ahmed, M., Navy, H. Vuthy, L. and Tiongo, M. 1998. Socio-economic Assessment of Freshwater Capture Fisheries of Cambodia. report on A Household Survey, Phnom Penh, Cambodia.

[25] Sithirith, M. and Mathur, V. 2008. "Entitlements and the Community Fishery in the Tonle Sap: Is the Fishing Lot System Still An Option for Inland Fisheries Management?" Fisheries Action Coalition Team's Paper.

[26] Van Acker, F. 2000. Don't trust fish when they are in the water: Cambodia's inland fisheries in transition. Unpublished paper. Phnom Penh.

[27] Degen, P., Van Acker, F., Van Zalinge, N., Thouk, N., and Vuthy, L. 2000. "Taken for Granted Conflict over Cambodia's Freshwater Fisheries Resources." In Proceedings of the 8th IASCP Conference, 31.

[28] Thouk, N. and Sina, L. 1997. Review of the Fisheries and Aquaculture Sector in Cambodia. Phnom Penh: Department of Fisheries, Cambodia.

[29] Bruce, M. and Yim, C. 2004. Domestic Fish Trade: A Case Study of Fish Marketing from the Great Lake to Phnom Penh. Phnom Penh: Cambodia Development Resource Institute (CDRI).

[30] Degen, P. \& Thouk, N. 2000. "Historical, Cultural and Legal Perspectives on the Fishing Lot System in Cambodia." In Proceedings of Common Property in the Mekong Issues of Sustainability and Subsistence, 15-64.

[31] Commune Database. 2008. The Baseline Data and the Population Data of Communes around the Tonle Sap Lake. Ministry of Interior, Cambodia. Accessed May 15, 2016. http://db.ncdd.gov.kh/cdbonline/home/index.castle.

[32] Cambodian Family Development Service (CFDS). 2002. The Participatory Rapid Appraisal Report (PRA) of Kampong La village. Pursat Province, Cambodia.

[33] Commune Development Plan. 2006. Commune Development Plan of Kampong Phluk. Siem Reap Provincial Government, Cambodia. 